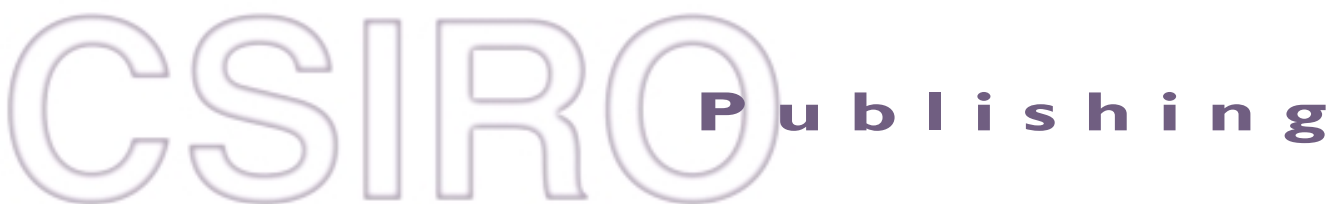

\section{Australian JOURNAL of B O T A N Y}

Volume 49, 2001

(c) CSIRO 2001

AN INTERNATIONAL JOURNAL FOR

THE PUBLICATION OF ORIGINAL

RESEARCH IN PLANT SCIENCE

All enquiries and manuscripts should be directed to:

Australian Journal of Botany

CSIRO Publishing

PO Box 1139 (150 Oxford St)

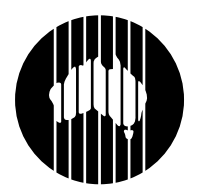

Collingwood, Vic. 3066, Australia

Telephone: +6139662 7613

Fax: +6139662 7611

C S I RO

Email: ajb@publish.csiro.au

Published by CSIRO Publishing

for CSIRO and the Australian Academy of Science

www.publish.csiro.au/journals/ajb 


\title{
Germination of dimorphic seeds of Suaeda moquinii under high salinity stress
}

\author{
M. Ajmal Khan ${ }^{\mathrm{A}}$, Bilquees Gul ${ }^{\mathrm{A}}$ and Darrell J. Weber ${ }^{\mathrm{B}}$ \\ Department of Botany and Range Science, Brigham Young University, Provo, Utah 84602-5181, USA. \\ ${ }^{A}$ Present address: Department of Botany, University of Karachi, Karachi-75270, Pakistan. \\ ${ }^{\mathrm{B}}$ Corresponding author; email: darrell_weber@byu.edu
}

\begin{abstract}
Suaeda moquinii (Torrey) Greene (desert blite), a succulent shrub in the family Chenopodiaceae, is widely distributed in salt marshes of the western United States. Suaeda moquinii produces dimorphic seeds (soft brown and hard black). Both types of seeds were collected from a salt marsh in Faust, Utah. Experiments were conducted to determine the seed germination responses of the black and brown seeds to salinity and temperature. Brown seeds were found to be one of the most salt tolerant at the germination stage when compared to other halophytes. Brown seeds germinated (30\%) at $1000 \mathrm{mM} \mathrm{NaCl}$, but only a few black seeds germinated (8\%) at 600 $\mathrm{mM} \mathrm{NaCl}$. Seed germination occurred in most saline treatments at the lowest thermoperiod $\left(5-15^{\circ} \mathrm{C}\right)$ tested. In some salinity treatments $(600,800,1000 \mathrm{mM})$, further increases in temperature resulted in progressively decreased seed germination. Brown seeds germinated better and had a higher germination rate (germination velocity) than black seeds at all thermoperiods. The highest rate of germination of black seeds occurred at the lowest thermoperiod $\left(5-15^{\circ} \mathrm{C}\right)$. Recovery of germination for black seeds when transferred to distilled water after being in various salinity treatments for 20 days was nearly complete $(82-100 \%)$ at the lowest thermoperiod $\left(5-15^{\circ} \mathrm{C}\right)$ but decreased with increase in the temperature. Brown seeds recovered substantially (59-97\%) from salinity at all thermoperiods. Regression analyses indicated significant differences between the germination recovery of the black and brown seeds.
\end{abstract}

\section{Introduction}

Salt marsh and salt desert environments vary both spatially and temporally showing environmental gradients and unpredictability of seasonal and annual conditions (Ungar 1995). Small microtopographic changes can lead to significant differences in water table and surface soil salinities. The ability to produce dimorphic or polymorphic seeds enables halophytes to respond to salt-marsh and saltdesert environments by either varying dispersal distance of seeds from plants or the dormancy level of seeds, which serves to extend the period of germination (Ungar 1991). Seeds of a number of halophytic species from India, including Suaeda fruticosa, are polymorphic, and the differences in seed mass and different soil salinity levels at the locations where these populations are growing could result in selection for seed size (Mohammad and Sen 1991). Genetic polymorphism also exists in distinct populations of the halophyte Suaeda maritima (Boucaud 1962). Seed dimorphism and polymorphism have been reported for a number of halophytic taxa including Arthrocnemum, Atriplex, Chenopodium, Cakile, Salicornia, Salsola, Spergularia, Suaeda and Trianthema (Ungar 1977; Khan and Ungar 1984; Galinato and van der Valk 1986;
Mohammad and Sen 1988; Ungar 1988; Morgan and Myers 1989; Khan and Gul 1998) and may have resulted in plasticity in their germination responses to varying environments.

The limit of salt tolerance varies among halophytes (Ungar 1995), and this variation could be due to a number of factors such as variation in the morphology (stem succulence, leaf succulence, secreting, non-secreting) and distribution (inland or coastal, temperate or tropical) (Baskin and Baskin 1998). Maximum salt tolerance at germination has been reported for Salicornia bigellovii (12\% germination at $856 \mathrm{mM} \mathrm{NaCl}$, Rivers and Weber 1971), Tamarix pentandra (29\% germination at $856 \mathrm{mM} \mathrm{NaCl}$, Ungar 1967), Salicornia utahensis (30\% germination at $856 \mathrm{mM} \mathrm{NaCl}$, Khan and Weber 1986), Cressa cretica (12\% germination at $856 \mathrm{mM} \mathrm{NaCl}$, Khan 1991), and Arthrocnemum indicum (3\% germination at $1000 \mathrm{mM} \mathrm{NaCl}$, Khan and Gul 1998). The limit of salt tolerance for Suaeda species varies from 400 $\mathrm{mM}$ to $800 \mathrm{mM} \mathrm{NaCl}$ (Ungar 1962; Ungar and Capilupo 1969; Clarke and Hannon 1970; Okusanya 1979; Yokoishi and Tanimoto 1994; Khan and Ungar 1999). Temperature interacts with salinity in determining the rate (germination velocity) and total germination percentages of halophyte 
Table 1. Results of three-way ANOVA of characteristics by seed colour, salinity, and thermoperiod treatments Values represent $F$-values: ${ }^{* * *} P<0.001$

\begin{tabular}{|c|c|c|c|c|c|c|c|}
\hline Independent variable & $\begin{array}{l}\text { Seed color } \\
\text { (SC) }\end{array}$ & $\begin{array}{l}\text { Salinity } \\
\text { (S) }\end{array}$ & $\begin{array}{c}\text { Thermoperiod } \\
\text { (T) }\end{array}$ & $\mathrm{SC} \times \mathrm{S}$ & $\mathrm{SC} \times \mathrm{T}$ & $\mathrm{T} \times \mathrm{S}$ & $\mathrm{SC} \times \mathrm{T} \times \mathrm{S}$ \\
\hline Final germination & $1636 * * *$ & $302 * * *$ & $34 * * *$ & $7 * * *$ & $19 * * *$ & $24 * * *$ & $8 * * *$ \\
\hline Rate of germination & $2297 * * *$ & $308 * * *$ & $10 * * *$ & $3 * * *$ & $45 * * *$ & $12 * * *$ & $3 * * *$ \\
\hline $\begin{array}{l}\text { Recovery rate of } \\
\text { germination }\end{array}$ & $87 * * *$ & $157 * * *$ & $17 * * *$ & $70 * * *$ & $6 * * *$ & $42 * * *$ & $10^{* * *}$ \\
\hline Percentage recovery & $20 * * *$ & $137 * * *$ & $21 * * *$ & $50 * * *$ & $6 * * *$ & $47 * * *$ & $10 * * *$ \\
\hline
\end{tabular}

seeds (Rajpurohit and Sen 1977; Khan and Weber 1986; Ismail 1990; Khan 1991; DeVilliers et al. 1994; Khan and Rizvi 1994; Khan and Ungar 1996, 1997, 1999; Gul and Weber 1999).

Some halophyte seeds can maintain viability after an extended exposure to salinity (Macke and Ungar 1971; Woodell 1985; Nolasco et al. 1996). However, only a few studies have focused on the effects of variation in thermoperiod on the recovery of halophytes after exposure to salinity (Khan and Ungar 1996, 1997, 1999; Gul and Weber 1999). Khan and Ungar (1997) reported that recovery of seed germination varies with species, and that some species are more sensitive to changes in thermoperiod.

Suaeda moquinii (Torrey) Greene (Chenopodiaceae) is a succulent shrub that dominates riparian (by rivers) or palustrian (boggy) habitats at 1125-1955 $\mathrm{m}$ in Utah, California, Nevada, Wyoming, Arizona and Mexico (Ferren and Schenk 1999). Suaeda moquinii exhibits much phenotypic plasticity and is widely distributed. It is commonly found with the salt desert shrub Sarcobatus vermiculatus, the forb Suaeda calceoliformis and the grass Distichlis spicata. Suaeda moquinii produce dimorphic seeds (soft brown and hard black) on the same plant. The environment where $S$. moquinii grows has a high variation in temperature from early spring to late summer. The moisture comes mainly as snow in the winter and by spring rains. The increase in temperature during the summer leads to greater water evaporation and subsequently an increase in salinity in the soil. Suaeda moquinii has been reported to be dominant on very highly saline soils that usually range between 80 and $100 \mathrm{dS} \mathrm{m}^{-1}$ (Gul 1998). The goal of this study was to examine the effects of high salinity and thermoperiod on the germination and recovery of brown and black seeds of Suaeda moquinii.

\section{Materials and methods}

Seeds of Suaeda moqunii were collected during the fall of 1996 from a salt marsh located at Faust, Utah, $48 \mathrm{~km}$ south of the Great Salt Lake. The soils were measured for EC values with a conductivity meter. Seeds were separated from the inflorescence, air dried and stored at $4^{\circ} \mathrm{C}$. Seeds were surface-sterilised by using the fungicide Phygon (2,3 dichloro-1,4- naphthoquinone). Germination was carried out in $50 \times 9$-mm tightfitting plastic petri dishes (Gelman No. 7232) with $5 \mathrm{~mL}$ of test solution as described below. Each of these dishes was placed in a 10-cm-diameter plastic petri dish to prevent the loss of water by evaporation. Four replicates of 25 seeds each were used for each treatment. Seeds were considered to be germinated with emergence of the radicle.

To determine the effects of temperature on germination, 12-h alternating temperature regimes of $5-15,10-20,15-25,20-30$ and $25-35^{\circ} \mathrm{C}$ were used. Seeds were germinated in distilled water or in 200 , $400,600,800$ and $1000 \mathrm{mM} \mathrm{NaCl}$ at the above-mentioned temperature regimes. The percentage germination was recorded every second day for 20 days. After 20 days, ungerminated seeds from the $\mathrm{NaCl}$ treatments were transferred to distilled water to study the recovery of germination, which was also recorded at 2-day intervals for 20 days. The recovery percentages were determined by the following formula: $(a-b) /(c-b) \times 100$, where $a$ is the total number of seeds germinated after being transferred to distilled water, $b$ is the total number of seeds germinated in saline solution and $c$ is the total number of seeds. The rate of germination was estimated by using a modified Timson index of germination velocity $=\Sigma G / t$, where $G$ is the percentage of seed germination at 2 days intervals and $t$ is the total germination period (Khan and Ungar 1984). The maximum value possible by this index with our data was 50 (i.e. 1000/20). The higher the value, the more rapid the rate of germination.

Germination data (20-day germination and rate of germination) were transformed (arcsine) before statistical analysis. Data were analysed by a three-way analysis of variance (SPSS Inc. 1997) to determine the significance of main effects (salinity, thermoperiod and seed type) and their interactions in affecting the rate and percentage of germination. If significant differences occurred a Bonferroni analysis (multiple range test $=$ modified 1.s.d., $P<0.05$ ) was carried out to determine whether significant differences occurred between individual treatments.

\section{Results}

Soils of the Suaeda moquinii community were highly saline with EC values of $80-100 \mathrm{dS} \mathrm{m}^{-1}$. Salinity, temperature and seed colour and their interactions affected the percentage seed germination, rate of germination, recovery and rate of recovery of $S$. moquinii (Table 1 ).

Germination of brown seeds was substantially faster and more complete than that of the black seeds (Fig. 1). Little germination of black seeds was recorded at or above $600 \mathrm{mM}$ $\mathrm{NaCl}$ (Fig. 1). The lowest thermoperiod $\left(5-15^{\circ} \mathrm{C}\right)$ was better for germination of black seed than for brown seeds. Seed 

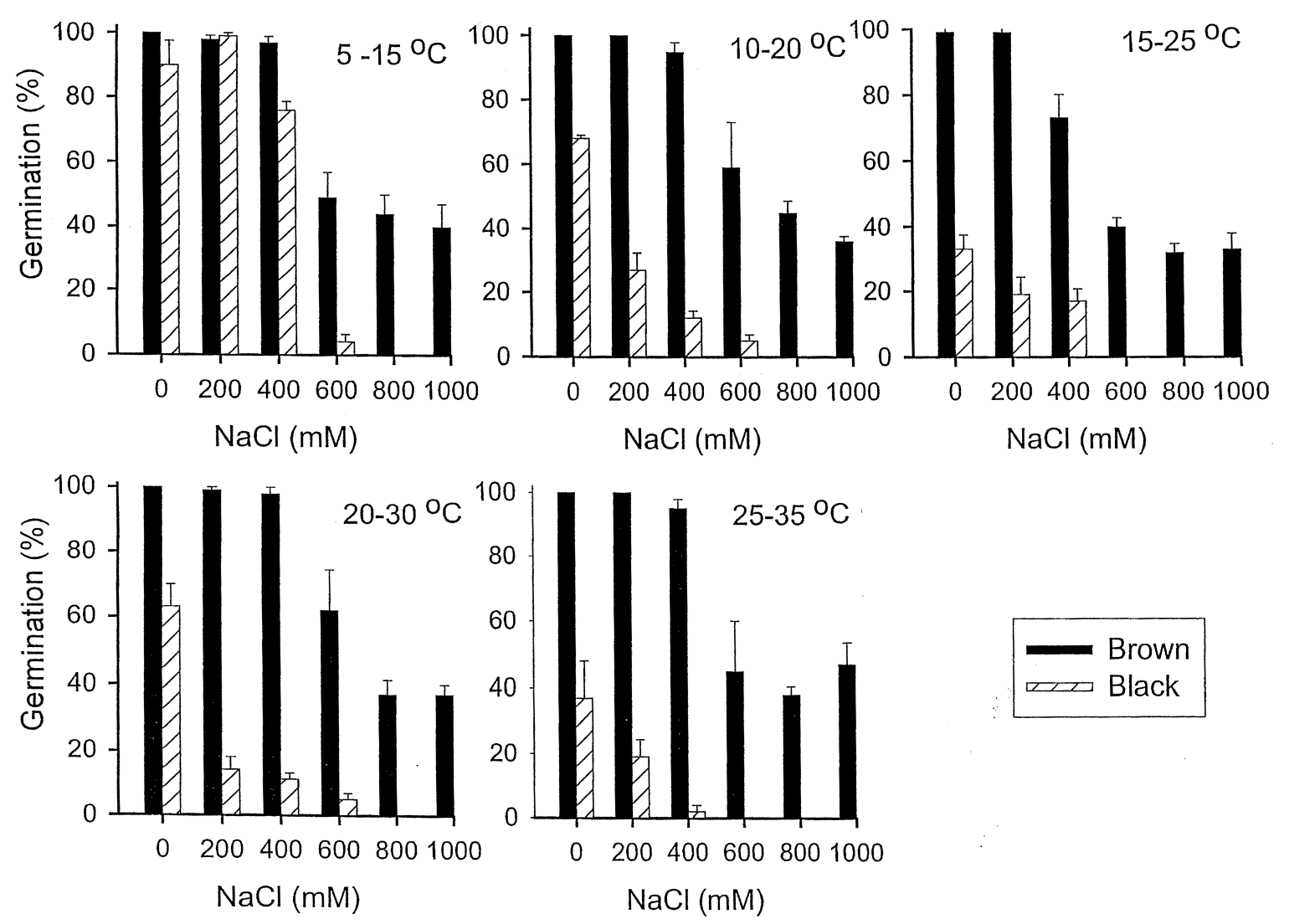

Fig. 1. Percentage germination (mean \pm s.e.) of brown and black seeds of Suaeda moquinii in 0, 200, 400, 600, 800 and $1000 \mathrm{mM}$ $\mathrm{NaCl}$ at thermoperiods of $5-15,10-20,15-25,20-30$ and $25-35^{\circ} \mathrm{C}$.

germination of black seeds decreased with increases in temperature and salinity. Brown seed showed 30\% germination at the highest salt treatment $(1000 \mathrm{mM} \mathrm{NaCl})$ and change in temperature had little effect (Fig. 1). In contrast, germination without $\mathrm{NaCl}$ was $100 \%$ for brown seeds and $95 \%$ for black seeds. Germination of brown seeds was not affected by either changes in salinity between 0 and $200 \mathrm{mM} \mathrm{NaCl}$ or in thermoperiods (Figs 1, 2). Germination at these salinity levels reached about $100 \%$ within about 6 days (Fig. 3).

The rate of germination of brown seeds was not affected by temperature (Fig. 2). Salinity up to $400 \mathrm{mM} \mathrm{NaCl}$ had no affect on the rate of germination of brown seeds. At higher salinity levels, the rate decreased. The rate of germination of black seed progressively decreased with increasing salinity. The fastest rate of germination of black seeds was obtained at $5-15^{\circ} \mathrm{C}$. The germination rate decreased with increasing temperature. The percentage of black seeds that germinated over the 20-day period was nearly linear at the low salinity levels and took about 20 days to reach 100\% (Fig. 4). In contrast, the brown seeds germinated almost $100 \%$ in about 6 days at the low salinity levels (Fig. 3).

Black seeds transferred to distilled water after 20 days of salinity treatment recovered quickly and completely at the lowest thermoperiod $\left(5-15^{\circ} \mathrm{C}\right.$ ) (Fig. 5). At the $25-35^{\circ} \mathrm{C}$ thermoperiod, only a few black seeds recovered at all salinity treatments. In contrast, brown seeds recovered almost completely at all thermoperiods from salinities of $600 \mathrm{mM}$ $\mathrm{NaCl}$ and above. The comparison of the regression lines indicate that there was a significant difference between the black and brown seed recovery, except at the $20-30^{\circ} \mathrm{C}$ thermoperiod (Fig. 5).

The recovery of the rate of germination of black seed was greatest at the lowest thermoperiod $\left(5-15^{\circ} \mathrm{C}\right)$ and progressively decreased with increasing temperature (Fig. 6). The recovery of the rate of germination was greater for brown seeds but remained unchanged with changes in thermoperiods and for salinities of $600 \mathrm{mM} \mathrm{NaCl}$ and above. The comparison of the regression lines indicated that there were significant differences in the rate of germination 

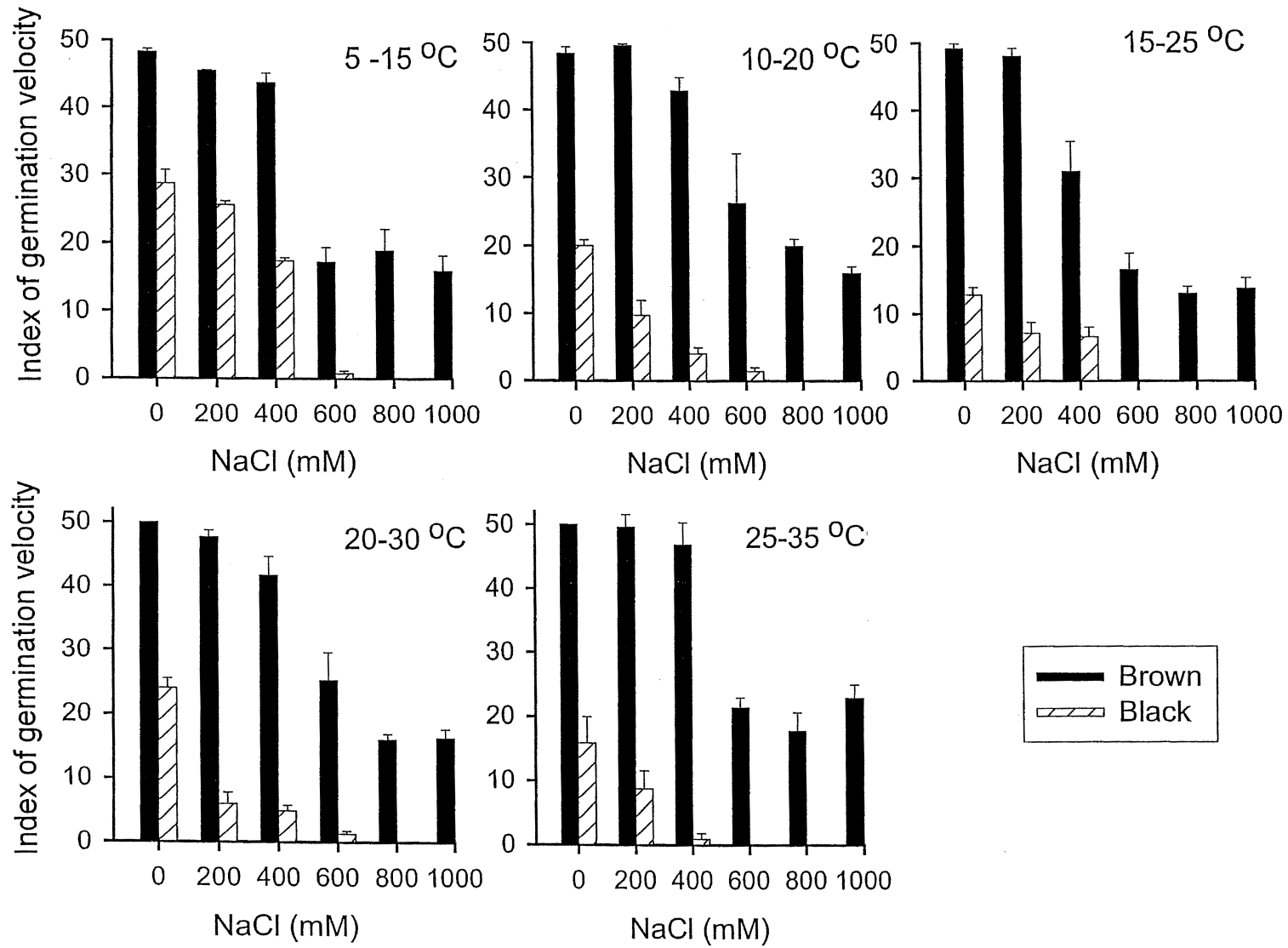

Fig. 2. Index of germination velocity (mean \pm s.e.) of brown and black seeds of Suaeda moquinii in $0,200,400,600,800$ and 1000 $\mathrm{mM} \mathrm{NaCl}$ at thermoperiods of $5-15,10-20,15-25,20-30$ and $25-35^{\circ} \mathrm{C}$.

between the black and brown seeds at $15-25^{\circ} \mathrm{C}$ and $25-35^{\circ} \mathrm{C}$ thermoperiods.

\section{Discussion}

Thirty per cent of brown seeds of $S$. moquinii germinated at $1000 \mathrm{mM} \mathrm{NaCl}$. The limits of salt tolerance vary somewhat among species of succulent halophytes (Ungar 1995), with some seeds of the stem succulent Salicornia europaea $(8 \%)$ and leaf succulent Suaeda linearis (1\%) germinating in up to $849 \mathrm{mM} \mathrm{NaCl}$ (Ungar 1962, 1967), while others such as Arthrocnemum indicum (3\%) having seeds that can germinate in $1000 \mathrm{mM} \mathrm{NaCl}$ (Khan and Gul 1998). There are other reports (Salicornia biglovia, Salicornia europaea, Cressa cretica) indicating some germination at the $\mathrm{NaCl}$ concentration above $800 \mathrm{mM}$ (Rivers and Weber 1971; Ungar 1979; Khan and Weber 1986; Khan 1991). Brown seeds of $S$. moquinii were among the most salt tolerant seeds at the germination stage. Suaeda moquinii seeds were collected from a population found in the salt marshes of Faust, Utah, along with other halophytes such as Atriplex patula, Distichlis spicata, Scirpus maritimus, Sarcobatus vermiculatus and Triglochin maritima with soil EC ranging from 850 to $1031 \mathrm{mM} \mathrm{NaCl}$ in the $S$. moquinii zone. Plants surviving in such a highly saline environment require a higher degree of salt tolerance during seed germination. Black seeds on $S$. moquinii on the other hand were not very tolerant to salinity. No seed germinated at concentrations higher than $600 \mathrm{mM} \mathrm{NaCl}$. Brown and black seed also differed greatly in their response to changes in thermoperiod. Black seeds germinated better at the lowest thermoperiod $\left(5-15^{\circ} \mathrm{C}\right)$ and increase in temperature caused a decrease in germination. Germination of brown seeds was not substantially affected by differences in thermoperiod. Salinity and temperature are reported to interact in their control of seed germination. The limits of tolerance to salinity may be greater at one thermoperiod than at another (Khan and Ungar 1984; Khan and Weber 1986; Badger and Ungar 1989; Ismail 1990; Khan 1991; Khan and Rizvi 1994; Khan and Ungar 1996, 1997, 1998, 1999; Khan and Gul 1998). Some species are more sensitive to change in temperature (Cressa cretica, Atriplex griffithii, Triglochin maritima, Polygonum aviculare and Zygophyllum simplex) than others (Arthrocnemum indicum, Haloxylon recurvum and Suaeda fruticosa) (Khan 1991; Khan and Rizvi 1994; 


\section{Brown seeds}

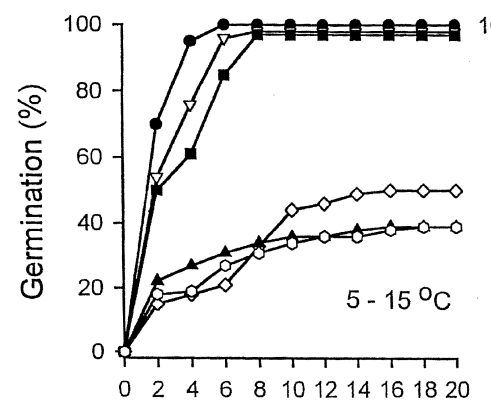

Days

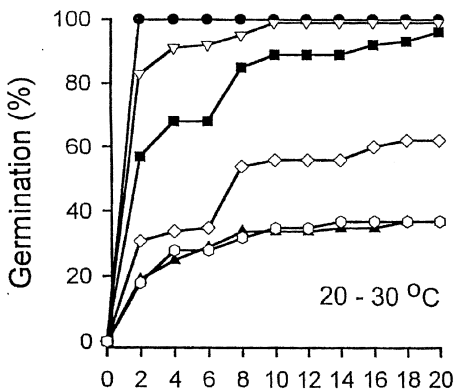

Days

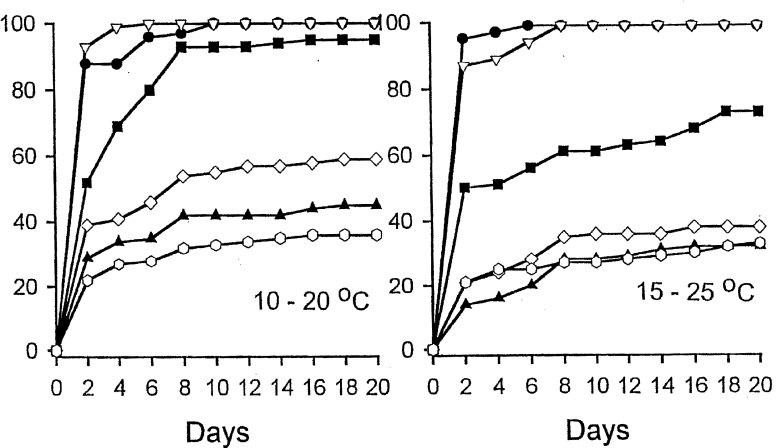

Fig. 3. Rate of germination (mean \pm s.e.) of brown seeds of Suaeda moquinii in $0,200,400,600,800$ and $1000 \mathrm{mM} \mathrm{NaCl}$ at thermoperiods of 5-15, 10-20, 15-25, 20-30 and $25-35^{\circ} \mathrm{C}$ over a 20 -day period.

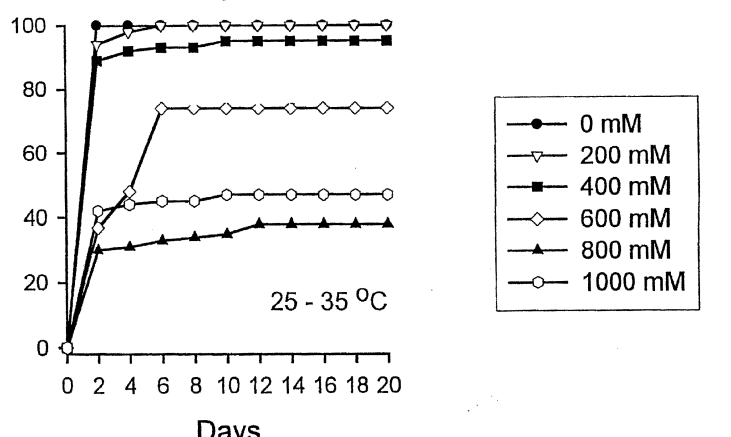

\section{Black seeds}
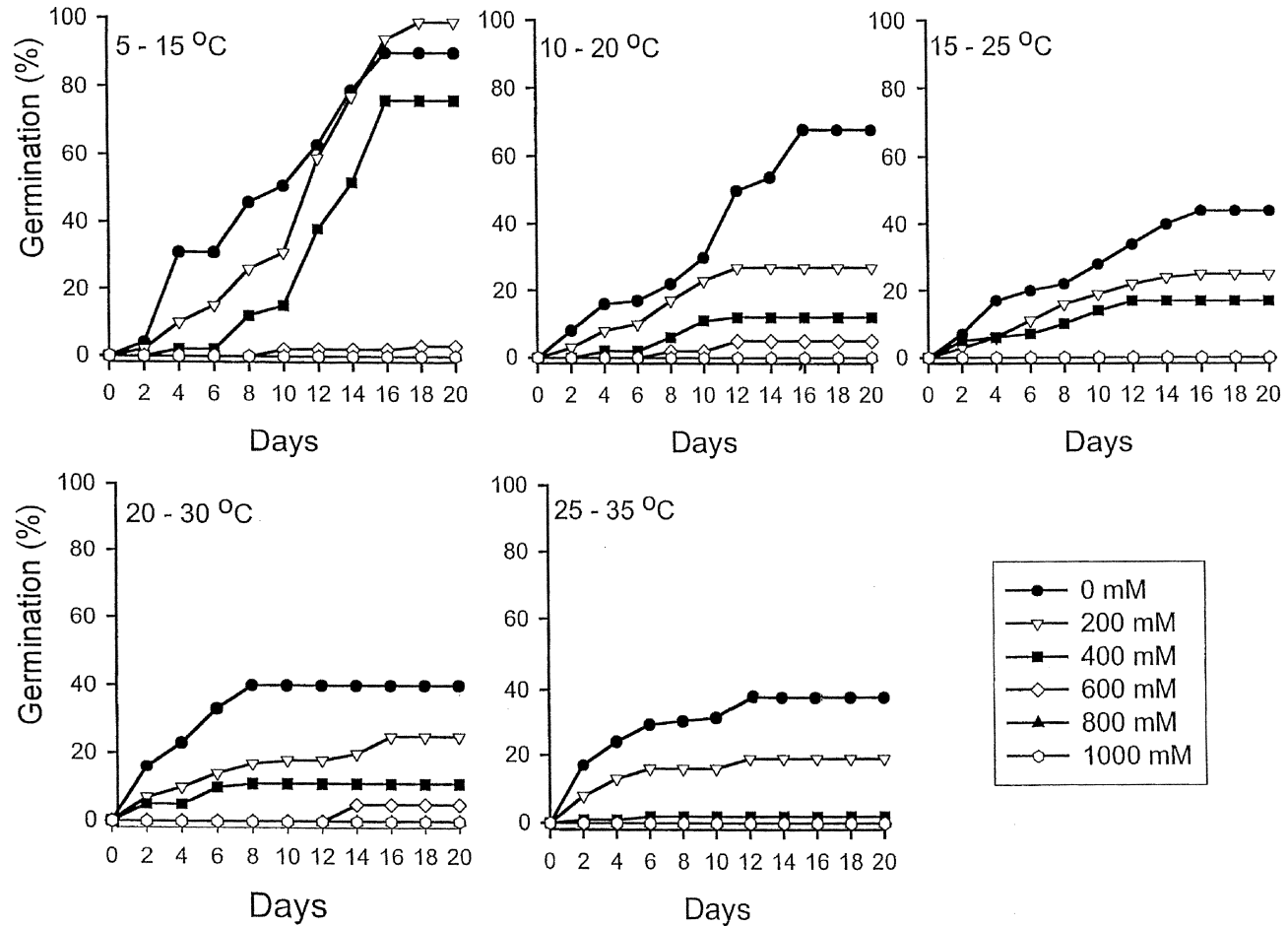

Fig. 4. Rate of germination (mean \pm s.e.) of black seeds of Suaeda moquinii in 0, 200, 400, 600, 800 and 1000 $\mathrm{mM} \mathrm{NaCl}$ at thermoperiods of $5-15,10-20,15-25,20-30$ and $25-35^{\circ} \mathrm{C}$ over a 20 -day period. 

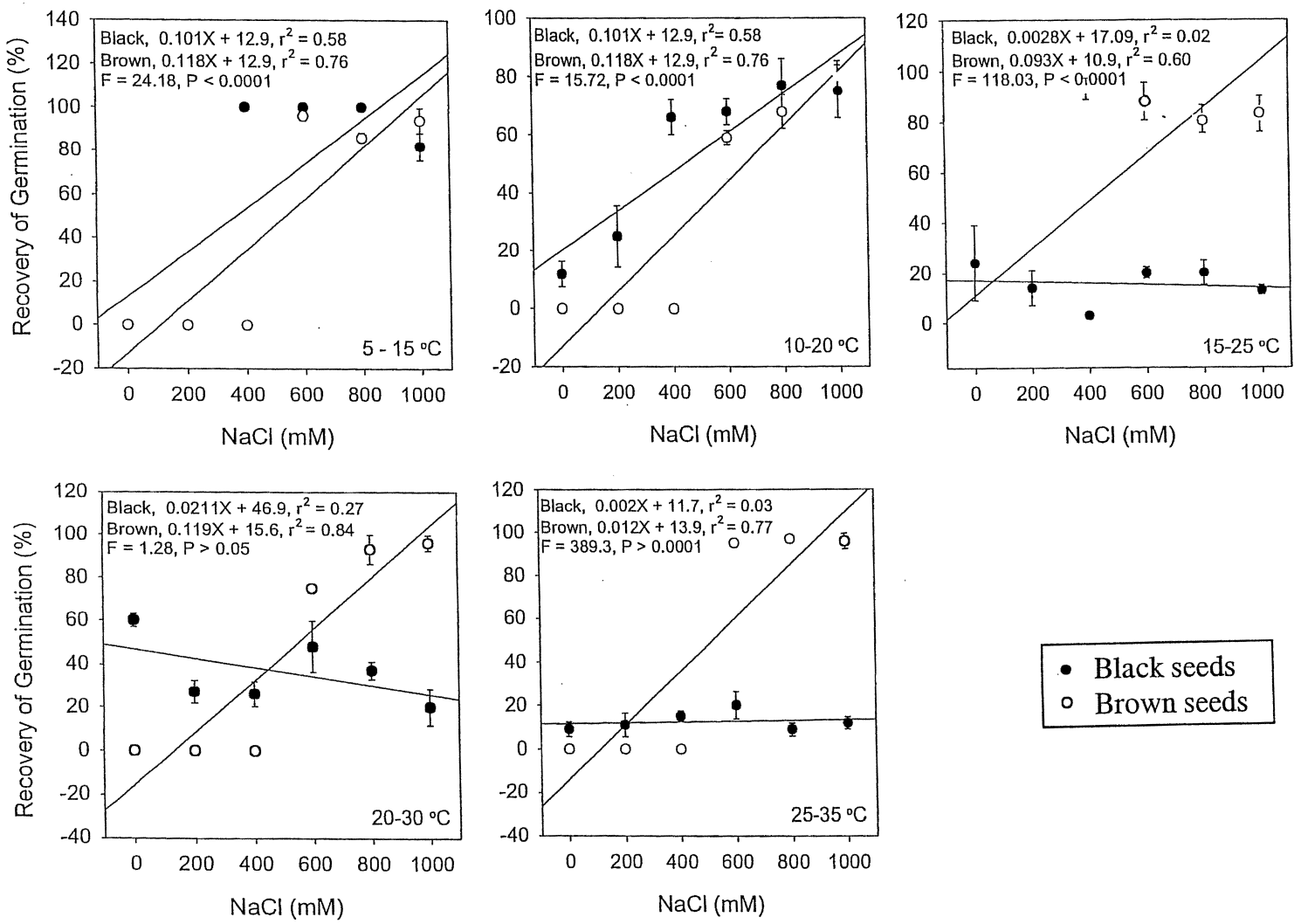

- Black seeds

- Brown seeds

Fig. 5. Regression curves of the recovery of germination (\%) of black ( $\bullet$ ) and brown (o) seeds of Suaeda moquinii after being in $0,200,400,600,800$ and $1000 \mathrm{mM} \mathrm{NaCl}$ at thermoperiods of 5-15, 10-20, 15-25, 20-30 and $25-35^{\circ} \mathrm{C}$ for a 20 -day period.

Khan and Ungar 1996, 1997, 1998; Khan and Gul 1998; Sheikh and Mahmood 1986).

When transferred to distilled water, recovery of germination of black seeds was complete at the lowest thermoperiod $\left(5-15^{\circ} \mathrm{C}\right)$ and decreased with increase in temperature. Warmer thermoperiods appeared to prevent the recovery of germination in black seeds. In contrast, brown seeds recovered quickly at all thermoperiods. Khan and Ungar (1997) found that the percentage of ungerminated seeds that recovered after they were transferred to distilled water differed significantly, with variation in species and thermoperiods. Zygophyllum simplex has little recovery at any of the $\mathrm{NaCl}$ concentrations in all thermoperiods. Haloxylon recurvum, Suaeda fruticosa and Triglochin maritima showed substantial recovery. Khan and Gul (1998) reported that seeds of Arthrocnemum indicum recovered quickly, and about $86 \%$ of the seeds recovered after exposure to high salinity $(1000 \mathrm{mM} \mathrm{NaCl})$. Similar recovery responses were also reported for Polygonum aviculare (Khan and Ungar 1998) and Suaeda fruticosa (Khan and Ungar 1999). Whereas non-dormant seeds of glycophytes may die when exposed to salinity (Partridge and Wilson 1987), those of halophytes do not (Mahmoud et al. 1983; SaadEddin and Doddema 1986).
Suaeda moqunii produces brown and black seeds on the same plant. Seed dimorphism has been reported for a number of halophytes (Ungar 1977; Khan and Ungar 1984; Galinato and van der Valk 1986; Mohammad and Sen 1988; Ungar 1988; Morgan and Myers 1989; Khan 1998; Khan and Gul 1998). It has been demonstrated that seed polymorphism provides an adaptive advantage in saline habitats through the production of multiple germination periods, which increases the chances of survival of at least some seedling cohorts (Ungar 1995). Suaeda moquinii usually grows as a thin stand of scraggly shrubs at the edge of and partly onto the largest playas where soil salinity is extremely high $\left(100 \mathrm{dS} \mathrm{m}^{-1}\right)$. This plant recruits through seeds and there is no evidence of vegetative propagation. It grows in areas characterised by great fluctuations in soil salinity and ambient temperature. The present study has shown that dimorphic seeds produced by this plant also differ physiologically in their response to temperature and salinity during germination. Black seeds are not very salt tolerant and germinate better during a cooler thermoperiod and may start germinating during the early part of spring when temperatures are cool and soil salinity is low due to moisture accumulating in playa from melting snow. Brown seeds, on the other hand, are most salt tolerant during germination, and the change in thermoperiod has little effect 

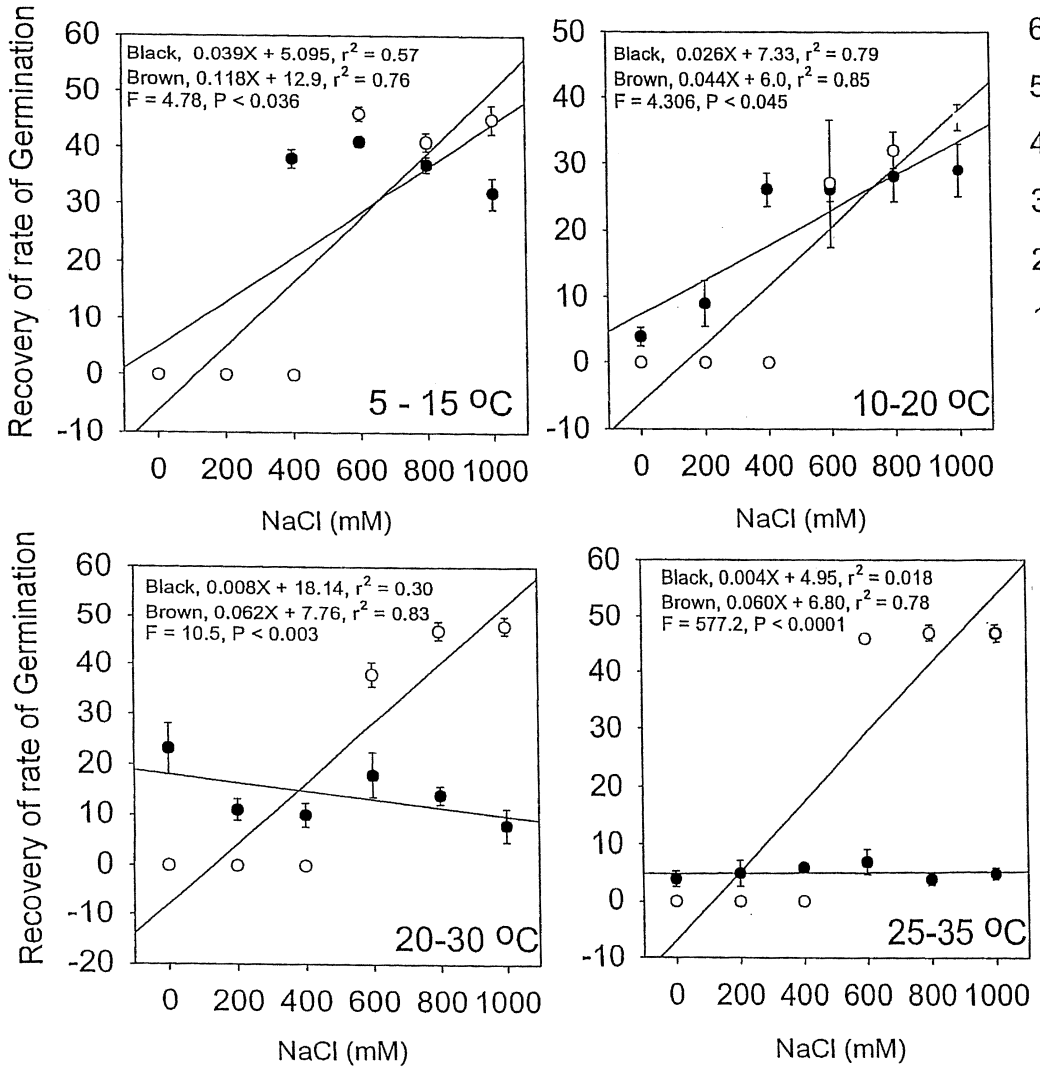

Fig. 6. Regression curves of the recovery of the rate of germination (\%) of black (•) and brown (o) seeds of Suaeda moquinii after being in $0,200,400,600,800$ and $1000 \mathrm{mM} \mathrm{NaCl}$ at thermoperiods of 5-15, 10-20, 15-25, 20-30 and 25-35 ${ }^{\circ}$ for a 20-day period.

on germination. Recruitment may occur through brown seeds from early spring to early summer periods. Salt marshes usually experience unexpected drought during some growing seasons. Any such drought incidence early in the spring could destroy the entire population of seedlings recruited either through black or brown seeds. At later stages with warmer and more saline conditions, brown seeds could germinate and maintain the fitness of the species. Our objective was to determine the physiological properties of the dimorphic seeds, and it would be interesting to conduct field studies to determine the ecological role of seed dimorphism in maintaining $S$. moquinii populations.

\section{Acknowledgments}

M. A. Khan thanks the Department of Botany and Range Science, Brigham Young University, for the award of Adjunct Professorship and associated facilities and University of Karachi for professional leave.

\section{References}

Badger KS, Ungar IA (1989) The effects of salinity and temperature on the germination of the inland halophyte Hordeum jubatum. Canadian Journal of Botany 67, 1420-1425.
Baskin CC, Baskin JM (1998) 'Seeds: ecology, biogeography and evolution of dormancy and germination.' (Academic Press: San Diego)

Boucaud J (1962) Etude morphologique et ecophysiologique de la germination trois varieties de Suaeda maritima Dum. Bulletin de la Societe Linneene de Normandie 3, 63-64.

Clarke LD, Hannon JD (1970) The mangrove swamp and salt marsh communities of the Sydney district. III. Plant growth in relation to salinity and water logging. Journal of Ecology 58, 351-369.

DeVilliers AJ, Van Rooyen MW, Theron CK, Van De Venter HA (1994) Germination of three Namaqualand pioneer species, as influenced by salinity, temperature, and light. Seed Science and Technology 22, 427-433.

Ferren WR, Schneke HJ (1999) Suaeda. In 'Flora of North America'. Vol. 4. (Oxford University Press: New York)

Galatino MI, Van der Valk AG (1986) Seed germination traits of annuals and emergents recruited during drawdowns in the Delta marsh, Manitoba, Canada. Aquatic Botany 26, 89-102.

Gul B (1998) Ecophysiology and population biology of the perennial halophytic shrub Allenrolfea occidentalis (S.Wats.) Kuntze (Chenopodiaceae) growing in a salt playa near Goshen, northwestern Utah. PhD Dissertation, Brigham Young University, USA.

Gul B, Weber DJ (1999) Effect of salinity, light and thermoperiod on the seed germination of Allenrolfea occidentalis. Canadian Journal of Botany 77, 240-246.

Ismail AMA (1990) Germination ecophysiology in populations of Zygophyllum qatarense Hadidi from contrasting habitats: effect of temperature, salinity and growth regulators with special reference to fusicoccin. Journal of Arid Environments 18, 185-194. 
Khan MA (1991) Studies on germination of Cressa cretica. Pakistan Journal Weed Science Research 4, 89-98.

Khan MA, Gul B (1998) High salt tolerance in germinating dimorphic seeds of Arthrocnemum indicum. International Journal of Plant Science 159, 826-832.

Khan MA, Rizvi Y (1994) Effect of salinity, temperature, and growth regulators on the germination and early seedling growth of Atriplex griffithii var. stocksii. Canadian Journal of Botany 72, 475-479.

Khan MA, Ungar IA (1984) The effect of salinity and temperature on the germination of polymorphic seeds and growth of Atriplex triangularis Willd. American Journal of Botany 71, 481-489.

Khan MA, Ungar IA (1996) Influence of salinity and temperature on the germination of Haloxylon recurvum. Annals of Botany 78, $547-551$.

Khan MA, Ungar IA (1997) Germination responses of the subtropical annual halophyte Zygophyllum simplex. Seed Science and Technology 25, 83-91.

Khan MA, Ungar IA (1998) Germination of salt tolerant shrub Suaeda fruticosa from Pakistan: salinity and temperature responses. Seed Science and Technology 26, 657-667.

Khan MA, Ungar IA (1999) Effects of salinity on the seed germination of Triglochin maritima under various thermoperiods. Great Basin Naturalist 59, 144-150.

Khan MA, Weber DJ (1986) Factors influencing seed germination in Salicornia pacifica var. utahensis. American Journal of Botany 73, 1163-1167.

Macke A, Ungar IA (1971) The effect of salinity on germination and early growth of Puccinellia nuttalliana. Canadian Journal of Botany 49, 515-520.

Mahmoud A, El Sheikh AM, Abdul Baset S (1983) Germination of two halophytes: Halopaplis perfoliata and Limonium axilare from Saudi Arabia. Journal of Arid Environment 6, 87-98.

Mohammad S, Sen DN (1988) A report on polymorphic seeds in halophytes. 1. Trianthema triquetra L. in Indian desert. Current Science 57, 616-617.

Mohammad S, Sen DN (1991) Polymorphism as an adaptation in seeds of halophytes in Indian desert. (Eds DN Sen, S Mohammad) In 'Proceeding of International Seed Symposium', (University of Jodhpur Press: Jodhpur, India).

Morgan WC, Myers BA (1989) Germination characteristics of the salt tolerant grass Diplachne fusca. I. Dormancy and temperature responses. Australian Journal of Botany 37, 225-237.

Nolasco HF, Vega-Villasante H, Romero-Schmidt L, Diaz-Rondero A (1996) The effect of salinity, acidity, light and temperature on the germination of seeds of cardon (Pachycreus pringlei (S.Wats.) Britton \& Rose, Cactaceae). Journal of Arid Environments 33, 87-94.
Okusanya OT (1979) An experimental investigation into the ecology of some maritime cliff species. II. Germination studies. Journal of Ecology 67, 293-304.

Patridge TR, Wilson JB (1987) Germination in relation to salinity in some plants of salt marshes in Otago, New Zealand. New Zealand Journal of Botany 25, 255-261.

Rajpurohit KS, Sen DN (1977) Soil salinity and seed germination under water stress. Transaction of Indian society for Desert Technology and University Center for Desert Studies 2, 106-110.

Rivers WG, Weber DJ (1971) The influence of salinity and temperature on the seed germination in Salicornia bigellovii. Physiologia Plantanrum 24, 73-75.

SaadEddin R, Doddema H (1986) Anatomy of the 'extreme' halophyte Arthrocnemum fruticosum (L.) Moq. in relation to its physiology. Annals of Botany 57, 531-544.

Sheikh KH, Mahmood K (1986) Some studies on field distribution and seed germination of Suaeda fruticosa and Sporobolus arabicus with reference to salinity and sodicity of the medium. Plant and Soil 94, $333-340$.

SPSS Inc (1996) SPSS:SPSS 7.0 for windows. (SPSS Inc.: USA).

Ungar IA (1962) Influence of salinity on seed germination in succulent halophytes. Ecology 43, 763-764.

Ungar IA (1967) Vegetation-soil relationships on saline soils in northern Kansas. American Midland Naturalist 78, 98-120.

Ungar IA (1977) Salinity, temperature, and growth regulator effects on seed germination of Salicornia europaea L. Aquatic Botany 3, 329-335.

Ungar IA (1979) Seed dimorphism in Salicornia europaea. Botanical Gazzette 140, 102-108.

Ungar IA (1988) Effects of the parental environment on the temperature requirements and salinity tolerance of Spergularia marina seeds. Botanical Gazzette 149, 432-436.

Ungar IA (1991) 'Ecophysiology of vascular halophytes.' (CRC Press: Boca Raton)

Ungar IA (1995) Seed germination and seed-bank ecology of halophytes. In 'Seed development and germination'. (Eds J Kigel, G Galili). pp. 599-628. (Marcel and Dekker Inc: New York)

Ungar IA, Capilupo F (1969) An ecological life history study of Suaeda depressa (Pursh) Wats. Advance Frontiers of Plant Science 23, $137-158$.

Woodell SRJ (1985) Salinity and seed germination patterns in coastal plants. Vegetatio 61, 223-229.

Yokoishi T, Tanimoto S (1994) Seed germination of the halophyte Suaeda japonica under salt stress. Journal of Plant Research 107, 385-388.

Manuscript received 5 April 2000, accepted 4 September 2000 